Ann. Biol. anim. Bioch. Biophys., I97I, 11 (4), 645-656.

\title{
THE EFFECT OF VARIOUS PROTEIN LEVELS IN FEED OF GOSLINGS DURING THE PREPARATORY PERIOD ON FATTY LIVER PRODUCTION AND BLOOD PLASMA COMPONENTS
}

\author{
I. NIR and M. PEREK \\ Department of Poultry Science and Animal Hygiene, \\ Faculty of Agriculture, Hebrew University Jerusalem, Rehovot, Israel
}

SUMMARY

Two experiments were carried out to study the effect of feeding high protein diets, during the preparatory fattening period, on fatty liver production in geese. Both experiments produced no effect on the weights and composition of the fatty livers, on body organs and on blood plasma lipid and protein pattern of the geese following fattening.

\section{INTRODUCTION}

To date no studies have been conducted on the protein requirements of the local Israeli goose during the preparatory period before fattening.

FIEURET (I954) claimed that protein-rich diets administered to goslings before fattening result in higher liver weights and quality. On the other hand, BIEIINSKI et al. (I968) reported that no response was achieved by feeding higher protein diets to goslings.

The present work was destinated to study the value of this technic on geese raised without pasture. The influence of high dietary protein levels before fattening, on the weight of the goose, on its blood plasma, on its liver weight and chemistry was found worthy of study.

\section{MATERIALS AND METHODS}

The geese used in the present experiments are crosses of 3 varieties: Toulouse, Embden and a local goose with Egyptian breed characteristics. The Toulouse and Embden varieties were introduced in Israel in the thirties to improve the local goose. 
Two experiments were carried out with 4 week old goslings, each consisting of 60 birds. Prior to the experiment they were fed a mash containing $21 \mathrm{p}$. roo protein ad libitum.

TABLE I

Composition of diets (p. Ioo) in experiments 1 and $2^{+}$ TABLEAU I

Composition des régimes (p. Ioo) dans les expériences 1 et 2

\begin{tabular}{|c|c|c|c|}
\hline Protein level & 16 & 21 & 28 \\
\hline Soya-bean meal & 10.0 & 26.0 & 43.0 \\
\hline Fish meal ..... & 4.0 & 4.0 & 6.0 \\
\hline Sorghum $\ldots \ldots \ldots \ldots \ldots \ldots$ & 80.2 & 64.1 & 45.0 \\
\hline Wheat bran. . . . . . . . . . & 3.0 & 3.0 & 3.0 \\
\hline DL-methionine $\ldots \ldots \ldots \ldots \ldots \ldots$ & 0.04 & 0.1 & 0.1 \\
\hline Calcium Carbonate ......... & 1.4 & 1.4 & 1.4 \\
\hline Di Calcium Phosphate ...... & 1.0 & 1.0 & 1.0 \\
\hline $\mathrm{NaCl}+$ micro elements $* \ldots \ldots$. & 0.3 & 0.3 & 0.3 \\
\hline Vitamin mixture ${ }^{* *} \ldots \ldots \ldots \ldots \ldots$ & 0.1 & 0.1 & 0.1 \\
\hline Protein as found $(\mathrm{N} \times 6.25) \ldots \ldots$ & 16.1 & 20.8 & 27.9 \\
\hline Metabolizable Energy $\Delta(\mathrm{kcal} / \mathrm{kg}) \ldots$ & 2988 & 2823 & 2643 \\
\hline
\end{tabular}

+ Experiment $1: 16$ and 21 p. 100 protein diets ; Experiment $2: 16$ and 28 p. 100 protein diets.

* Certified to supply per ton mash : Manganese $120 \mathrm{~g}$, Zinc $50 \mathrm{~g}$, Copper $2.5 \mathrm{~g}$, Iron $25 \mathrm{~g}$, Cobalt $0.2 \mathrm{~g}$, Iodine $1.4 \mathrm{~g}$.

** Certified to supply per ton mash : Vitamin A 10000000 I. U., Vitamin $\mathrm{D}_{3} 2000000$ I. U., Vitamin E 10000 I. U., Vitamin K 3 g, Riboflavin $7 \mathrm{~g}$, Pantothenic Acid $12 \mathrm{~g}$, Niacin $25 \mathrm{~g}$, Choline Chloride $600 \mathrm{~g}$, Pyridoxine $2 \mathrm{~g}$, Folic Acid $0.5 \mathrm{~g}$, Vitamin $\mathrm{B}_{12} 10 \mathrm{mg}$, Biotin $80 \mathrm{mg}$, Ethoxyquin $120 \mathrm{~g}$.

$\Delta$ According to N. R. C.

\section{Experiment 1}

This experiment was performed from January until May on 2 groups of 30 goslings each, fed a mash containing $\mathrm{I} 6 \mathrm{p}$. Ioo and $21 \mathrm{p}$. Ioo protein respectively (table I) and supplemented with carrots (Ioo- $50 / g /$ day/bird) from the age of 7 weeks. These diets were fed ad libitum from 4 to II weeks of age, prior to the fattening period.

The forced feeding diet consisted of cooked maize supplemented with I p. roo soy oil and $3 \mathrm{~g} \mathrm{NaCl}$ per kg. One $\mathrm{g}$ of vitamin concentrate ${ }^{(1)}$ was given daily to each goose during the first 3 weeks of forced feeding. During the first week each group received a daily average of $250 \mathrm{~g}$ cooked maize divided into two meals. During the second and third weeks the amount of feed was increased to $5^{\circ 0}$ and $750 \mathrm{~g}$ respectively, reaching $900 \mathrm{~g}$ at the end of the cramming period (4-5 weeks) while the number of meals was increased to three daily. No individual record was kept on feed consumption. An average of $20 \mathrm{~kg}$ maize per bird was consumed. The animals were sacrificed after 28-34 days, i.e. when the oesophagi of the birds stopped emptying between meals. Before the fattening period 6 geese of each group were sacrificed for organ and blood examinations.

\section{Experiment 2}

This experiment was conducted during the hot summer season from June to October. Sixty birds divided into 2 equal groups were used from the age of $4-I_{4}$ weeks. One group received a

(1) Certified to contain in I kg : Vit. A $3300000 \mathrm{IU}$; D 330 000 IU; E, $400 \mathrm{mg}$; $\mathrm{B}_{12}, \mathrm{I} \mathrm{mg}$; $\mathrm{K}, 4 \mathrm{mg}$; Pantotenic acid, I.5 g; Riboflavin, $0.5 \mathrm{~g}$; Choline chloride, $30 \mathrm{~g}$; Niacin, $2 \mathrm{~g}$ and Pyridoxine $0.6 \mathrm{~g}$. 
mash containing I6 p. Ioo and the other $28 \mathrm{p}$. Ioo protein (table $\mathrm{I}$ ). In addition both groups had free access to cut green alfalfa until the fattening period. Forced feeding was carried out as in experiment $I$.

\section{Blood and organ examination}

Blood samples were drawn from wing vein using heparin as anticoagulant. The samples were taken between 9-ro a.m. -3 to 4 hours following the morning meal of the forced-fed geese. For hematocrit determination, each blood sample was centrifuged in a graduate tube at 2 ooo r.p.m. for Io minutes. The values obtained by this method were I.I4 times higher than those obtained by the micro-hematocrit method. The blood plasma was stored at $-22{ }^{\circ} \mathrm{C}$ for chemical analysis. At autopsy, œsophagi, gonads, thyroids, adrenals, kidneys, pancreas, abdominal adipose tissue and livers were dissected, freshly weighed, and the latter frozen on dry ice and then transferred to a deep freezer at $-22^{\circ} \mathrm{C}$. Breast muscle tissue, as with all other organs and glands, were carefully removed from the adhering fatty tissues before weighing and freezing.

\section{Chemical methods}

Plasma triglycerides were determined according to VAN HANDEL (r96I) and lipid P according to YoungBourg and YoungBourg (1930), using chloroform-methanol 2 : I instead of the ether-ethanol mixture proposed. Plasma total cholesterol determination was conducted according to ABELL et al. (1952) except that the reaction for the measurement of the cholesterol was carried out with the ferrous sulfate reagent according to SEARCy and BERGguIST (I960). Plasma free fatty acids were determined according to ITAYA and UI (I965). Glucose determination was performed according to NELson (I944).

Plasma total protein determination was conducted by the biuret reagent using bovine albumin as standard. In lipemic plasma, the plasma-biuret reagent mixture was extracted with ether before the determination of the optical density. Extraction with ether had no effect on colour development.

Plasma protein fractions were determined by electrophoresis on cellulose acetate using the Beckman, model R-Ioo Microzone electrophoresis system and the relative amount of the protein fractions by densitometry with the Beckman Model-R densitometer.

For the determination of total lipids in liver and muscle, aliquots were triturated with anhydrous $\mathrm{Na}_{2} \mathrm{SO}_{4}$ and extracted with ether for 8 hours. The ether extract was evaporated, dried in vacuo and weighed. Lipid fractions were determined on liver homogenates by the methods used for plasma. Nitrogen in liver and muscle were determined by the micro-Kjeldahl method.

\section{RESULTS}

As seen in figure $I$, no significant effect was observed in weight gains between the groups of birds fed different protein levels, in each of the experiments respectively. The lower weight gains obtained in the pre-fattening period of Experiment 2, may be attributed to the hot summer climatic conditions.

During the $0-4$ week period, prior to treatment, the feed/gain $(F / G)$ was 2.Io for all the birds in both experiments. During the 4-II week period (treatment period) the $F / G$ in the groups of experiment I was 5.48 for the $I 6$ p. Ioo protein group and 4.87 for the $21 \mathrm{p}$. Ioo protein group.

In Experiment 2, during the same period the $\mathrm{F} / \mathrm{G}$ was similar in both groups (5.47-5.35) receiving the $I 6$ and $28 \mathrm{p}$. Ioo protein diets respectively. The supplemented carrots or alfalfa were not taken into account in $F / G$ calculations. Since the body weights of the birds in Experiment 2 (summer) showed lower values than those in Experiment $I$, of the same age, the pre-fattening period was prolonged up to I4 weeks of age instead of II weeks. However, during this supplemental period the body gains were almost nil, and this, in spite of a normal food intake. 


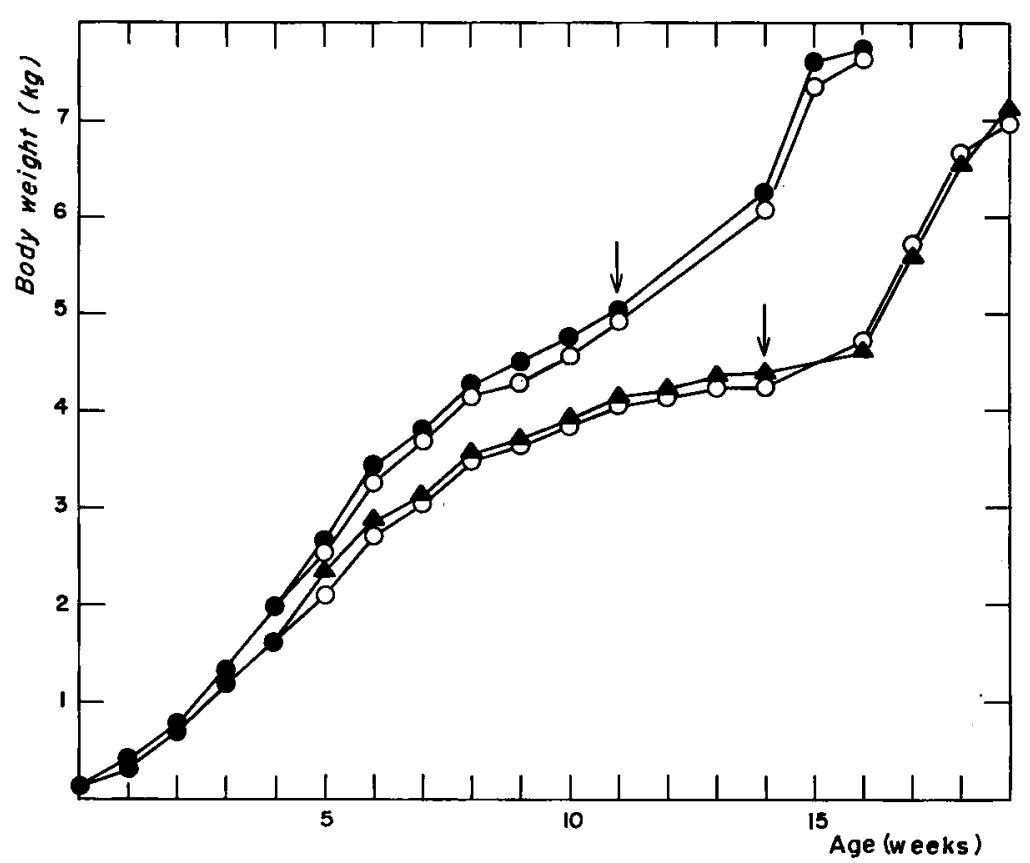

FIG. I. - Growth curves of the different groups fed diets containing 21 p. 100 protein from 0 to 4 weeks and 16, 21 or 18 p. 100 protein from 4 weeks of age to the start of forced feeding with cooked maize. (Arrows indicate start of forced feeding in exp. I (higher curves) and in exp. 2 (lower curves)).
I6 p. Ioo protein 0
2 I p. Ioo protein
(3o geese per treatment)

FIG. I. - Courbes de croissance des différents groupes recevant un régime contenant 21 p. 100 de protéines de 0 à 4 semaines et 16, 21 ou 28 p. 100 de protéines de l'âge de 4 semaines au début du gavage au mä̈s cuit. (Les flèches indiquent le début du gavage dans l'expérience I (courbes supérieures) et dans l'expérienec 2 (courbes inférieures)).

\section{Organ weight at end of pre-fattening period}

The data presented in table 2 are the averages of organ weight as related to live weight at sacrifice. Since sex showed no effect on relative organ weight, organs of both sexes were averaged together.

In Experiment I (winter) the weights of livers were significantly greater in birds fed the $2 \mathrm{I}$ p. Ioo protein diet as compared to those fed the $16 \mathrm{p}$. roo protein diet. In Experiment 2 (summer) with $28 \mathrm{p}$. Ioo and I6 p. Ioo protein diets, the higher protein level did not produce the same effect at the end of the pre-fattening period. However, the $28 \mathrm{p}$. Ioo protein diet did cause a statistically significant increase in pancreas and kidney weights. The weights of thyroids, adrenals, gonads and abdominal adipose tissue were not influenced by the protein level of the diet in either experiment.

It should be pointed out that the relative weights of livers, abdominal adipose tissue and pancreas were heavier and the oesophagi lighter in Experiment I as compared to Experiment 2. No differences were observed between the two experiments in regard to weights of thyroids and adrenals. 


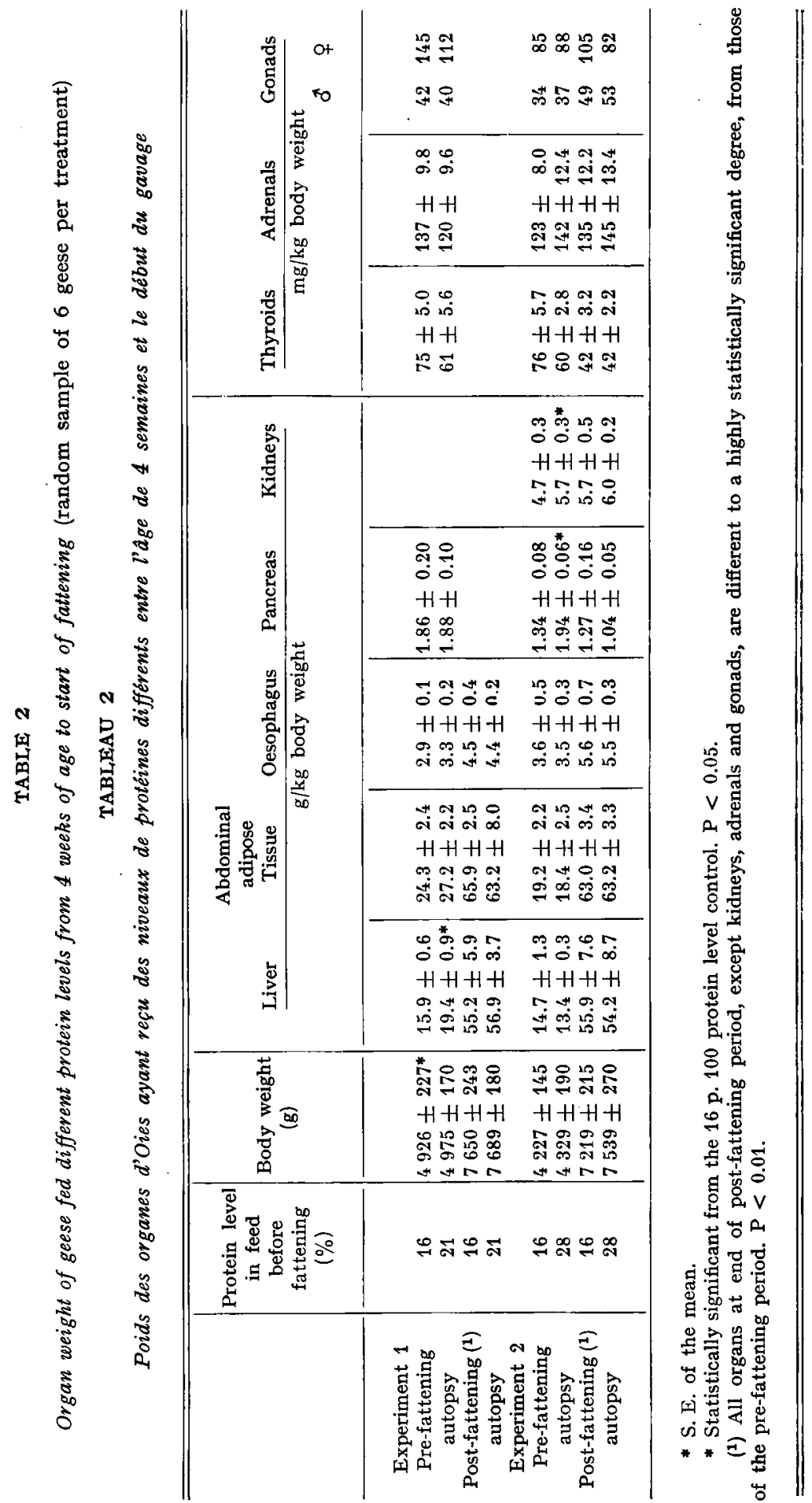


TABLE 3

Liver and muscle composition of geese fed different protein levels from 4 weeks of age to start of fattening

(exp. I-II weeks; exp. 2-I 4 weeks) (6 geese per treatment)

\section{TABLEAU 3}

Composition du foie et des muscles d'Oies ayant reçu des niveaux protéiques différents entre l'age de 4 semaines et le début du gavage (exp. I-II semaines; exp. 2-I4 semaines)

\begin{tabular}{|c|c|c|c|c|c|c|}
\hline & \multirow{2}{*}{$\begin{array}{c}\text { Protein level } \\
\text { in feed } \\
\text { before } \\
\text { fattening }\end{array}$} & \multirow{2}{*}{$\begin{array}{l}\text { Total } \\
\text { lipid } \\
(\%)\end{array}$} & \multicolumn{2}{|c|}{ Liver } & \multirow{2}{*}{$\begin{array}{c}\text { Total } \\
\text { Protein } \\
(\mathrm{N} \times 6.25) \\
(\%)\end{array}$} & \multirow{2}{*}{$\begin{array}{c}\text { Breast } \\
\text { Muscle } \\
\text { Total lipid } \\
(\%)\end{array}$} \\
\hline & & & $\begin{array}{c}\text { Total } \\
\text { Cholesterol } \\
(\mathrm{mg} \%)\end{array}$ & $\begin{array}{l}\text { Lipid P } \\
(\mathrm{mg} \%)\end{array}$ & & \\
\hline \multicolumn{7}{|l|}{ Experiment 1} \\
\hline Pre-fattening . . . . . & 16 & $3.2 \pm 0.2^{*}$ & $390 \pm 22$ & $62 \pm 2.7$ & $15.1 \pm 0.7$ & $2.7 \pm 0.2$ \\
\hline Autopsy $\ldots \ldots \ldots$. & 21 & $3.1 \pm 0.2$ & $397 \pm 34$ & $63 \pm 3.4$ & $14.7 \pm 0.4$ & $2.8 \pm 0.2$ \\
\hline Post-fattening $\ldots \ldots$ & 16 & $35.9 \pm 3.5$ & $677 \pm 10^{4}$ & $48 \pm 2.5$ & $9.3 \pm 0.6$ & \\
\hline Autopsy ( $\left.{ }^{(}\right)$ & 21 & $39.1 \pm 2.2$ & $914 \pm 152$ & $44 \pm 3.3$ & $8.5 \pm 0.3$ & \\
\hline \multicolumn{7}{|l|}{ Experiment 2} \\
\hline Pre-fattening & 16 & $4.7 \pm 0.6$ & $471 \pm 30$ & $100 \pm 7.3$ & $22.9 \pm \mathbf{0 . 9}$ & $3.3 \pm 0.4$ \\
\hline Autopsy & 28 & $4.5 \pm 0.7$ & $446 \pm \quad 37$ & $107 \pm 2.3$ & $25.3 \pm 0.8$ & $2.9 \pm 0.3$ \\
\hline Post-fattening $\ldots \ldots$ & 16 & $43.6 \pm 3.1$ & $696 \pm 49$ & $78 \pm 5.4$ & $10.6 \pm 0.8$ & $6.2 \pm 0.8$ \\
\hline Autopsy (1) $\ldots \ldots$. & 28 & $43.2 \pm 4.4$ & 697 土 56 & $74 \pm 12.4$ & $9.7 \pm 1.3$ & $5.9 \pm 1.0$ \\
\hline
\end{tabular}

* S. E. of the mean.

(') All data from the post fattening period is different to a highly statistically significant degre from the data of the pre-fattening period. $P<0.01$.

Hematocrit, plasma sugar and lipids of geese fed different protein levels from 4 we

Hématocrite, lipides et sucre plasmatiques d'Oies ayant reçu des nivec

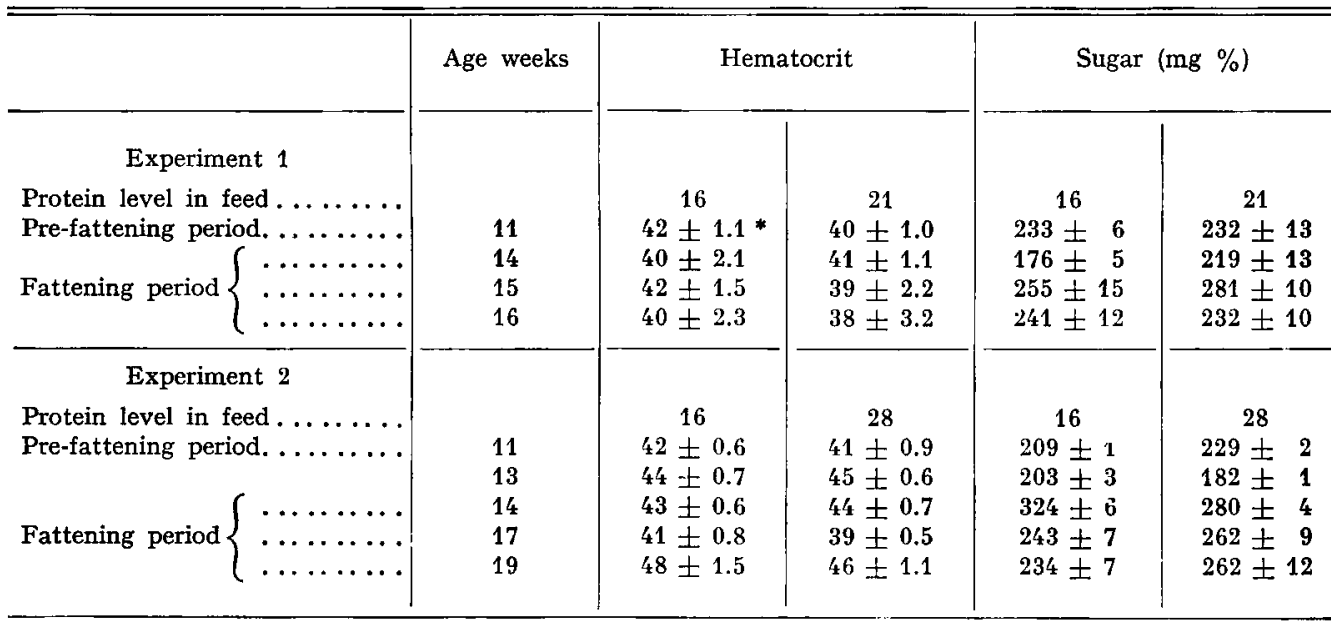

* S. E. of the mean. 


\section{Weight gains during the fattening period}

The weight curves presented in figure I show that the different protein levels supplied prior to fattening had no effect on weight gain during the fattening period in either experiment.

During the last week of fattening the rate of increase in weight gain declined despite maximal daily intake (900 $\mathrm{g} /$ maize/goose).

\section{Organ weight at end of fattening period}

The average increases in organ weight, in the high protein level groups, did not persist following fattening (table 2).

Fattening caused a marked increase in the relative weight of liver, oesophagus and abdominal adipose tissue, while a decrease was noted in the relative weights of pancreas and thyroids. No change occurred in the relative weight of the adrenals. Since a limited number of males (3) and females (3) were examined at each period and in each treatment, the effect of fattening on the gonad weight could not be considered. Obviously, the geese were found to be sexually undeveloped during the experiment.

\section{Liver and muscle composition}

Total lipids of muscles and livers and total protein of the livers were not affected by feeding diets with higher protein levels prior to fattening (table 3 ).

age to start of fattening (random sample of 6 geese per treatment and period)

AU 4

otéiques différents de l'âge de 4 semaines au début du gavage

\begin{tabular}{|c|c|c|c|c|c|c|c|}
\hline \multicolumn{2}{|c|}{ Triglycerides (mg \%) } & \multicolumn{2}{|c|}{ Total Cholesterol (mg \%) } & \multicolumn{2}{|c|}{ Lipid P (mg \%) } & \multicolumn{2}{|c|}{ FFA ( $(\mu \mathrm{eq} . / 100 \mathrm{ml})$} \\
\hline $\begin{array}{cc} & 16 \\
& 67 \pm 3 \\
1 & 906 \pm 779 \\
1 & 850 \pm 1247 \\
1 & 902 \pm 1408\end{array}$ & 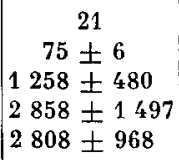 & $\begin{array}{c}16 \\
112 \pm 15 \\
172 \pm 13 \\
248 \pm 31 \\
270 \pm 22\end{array}$ & $\begin{array}{c}21 \\
145 \pm 15 \\
170 \pm 13 \\
246 \pm 30 \\
276 \pm 17\end{array}$ & $\begin{array}{c}16 \\
4.3 \pm 0.2 \\
13.5 \pm 2.2 \\
11.7 \pm 1.0 \\
14.1 \pm 2.2\end{array}$ & $\begin{array}{c}21 \\
4.5 \pm 0.3 \\
12.6 \pm 0.9 \\
13.3 \pm 2.2 \\
13.2 \pm 2.0\end{array}$ & $\begin{array}{c}16 \\
71 \pm 13 \\
171 \pm 9 \\
199 \pm 27 \\
183 \pm 44\end{array}$ & $\begin{array}{c}21 \\
63 \pm 8 \\
141 \pm 16 \\
179 \pm 49 \\
142 \pm 18\end{array}$ \\
\hline $\begin{array}{r}16 \\
97 \pm 7 \\
146 \pm 35 \\
84 \pm 7 \\
249 \pm 37 \\
419 \pm 40\end{array}$ & $\begin{array}{c}28 \\
170 \pm 5 \\
135 \pm 8 \\
73 \pm 3 \\
182 \pm 22 \\
352 \pm 14\end{array}$ & $\begin{array}{c}16 \\
127 \pm 15 \\
179 \pm 20 \\
191 \pm 10 \\
201 \pm 19 \\
352 \pm 14\end{array}$ & $\begin{array}{c}28 \\
162 \pm 5 \\
164 \pm 14 \\
201 \pm 10 \\
191 \pm 12 \\
311 \pm 23\end{array}$ & $\begin{array}{c}16 \\
13.1 \pm 0.6 \\
12.0 \pm 0.9 \\
12.6 \pm 0.6 \\
30.1 \pm 2.2 \\
27.3 \pm 2.4\end{array}$ & $\begin{array}{c}28 \\
15.7 \pm 0.8 \\
12.0 \pm 0.6 \\
13.7 \pm 0.4 \\
22.5 \pm 1.7 \\
19.6 \pm 2.1\end{array}$ & $\begin{array}{c}16 \\
116 \pm 8 \\
120 \pm 26 \\
189 \pm 29\end{array}$ & $\begin{array}{c}28 \\
76 \pm 2 \\
89 \pm 14 \\
132 \pm 16\end{array}$ \\
\hline
\end{tabular}


During the fattening period, the total lipid fraction in the livers increased ten fold in both experiments. Since cholesterol concentration was only doubled in the fatty livers and since a decrease was obtained in the phospholipid concentration, it is obvious that the main increase in the total lipid fraction of the fatty livers is due to triglycerides. The livers of the geese raised during the summer period contained more total lipids and lipids $P$ (Exp. 2) than the livers of the ones raised during the winter season (Exp. I). This difference was not found in the cholesterol concentration.

The total protein content of the liver before fattening was significantly higher in Experiment 2 ; however, this difference was not maintained after fattening.

\section{Hematocrit, plasma lipid and glucose}

The various protein levels administered during the pre-fattening period did not cause a difference on the hematocrit, plasma lipids and plasma sugar before and during the fattening period (table 4). Forced feeding increased plasma lipid components but had no effect on plasma glucose. However, the following differences were observed between the summer and winter raised geese (Exp. 2 and I respectively).

In the summer geese, hematocrit was higher and increased significantly during the last week of fattening. Higher levels of lipid $\mathrm{P}$ before and during fattening were parallel to lower levels of triglycerides obtained during the fattening period. Higher levels of lipid $\mathbf{P}$ were also found in the liver (table 3 ). In the winter-fattened geese a tremendous increase of plasma triglycerides was noted. Three weeks following start of forced-feeding the plasma triglycerides were over I p. roo and in the fourth and fifth weeks of fattening the average triglyceride value reached $2 \mathrm{p}$. Ioo and 3 p. Ioo respectively. In the summer experiments no higher values than $0.5 \mathrm{p}$. Ioo of triglycerides were obtained.

The plasma free fatty acids level was lower in the high protein diets fed groups (2I and 28 p. IOo) than in those fed the I6 p. Ioo protein diets. While not statistically significant, because of the very high variation between birds, the difference persisted during all periods and even after the experimental diets were replaced by cooked maize.

\section{The plasma proteins}

Plasma proteins were studied in Experiment 2 only (fig. 2). Electrophoresis of the plasma separated 5 fractions which were designed according to their migration rate (NIR and ASCARELII, I966). In contrast to chicken plasma all the samples drawn from the geese contained a fraction migrating before the albumin which we called the pre-albumin fraction.

The higher level of total plasma protein found during the pre-fattening period in the $28 \mathrm{p}$. Ioo protein group was not caused by higher amounts of a specific protein fraction ; the differences in the plasma protein fractions were slight and not consistent. Following fattening with maize abolished the prior effect caused by the high protein diet. The increase in protein level caused by fattening was essentially due to $b$-and partly to $a$-globulins. The increase of these fractions compensated for the decrease in albumin which was substantial following the first 3 weeks of forced feeding and very marked during the following 2 weeks. 
The behaviour of $g$-globulins before and during the fattening period was not consistent. The tendency to decrease during the pre-fattening period (II-I4 weeks) continued during the first 3 weeks of fattening but was reversed during the last

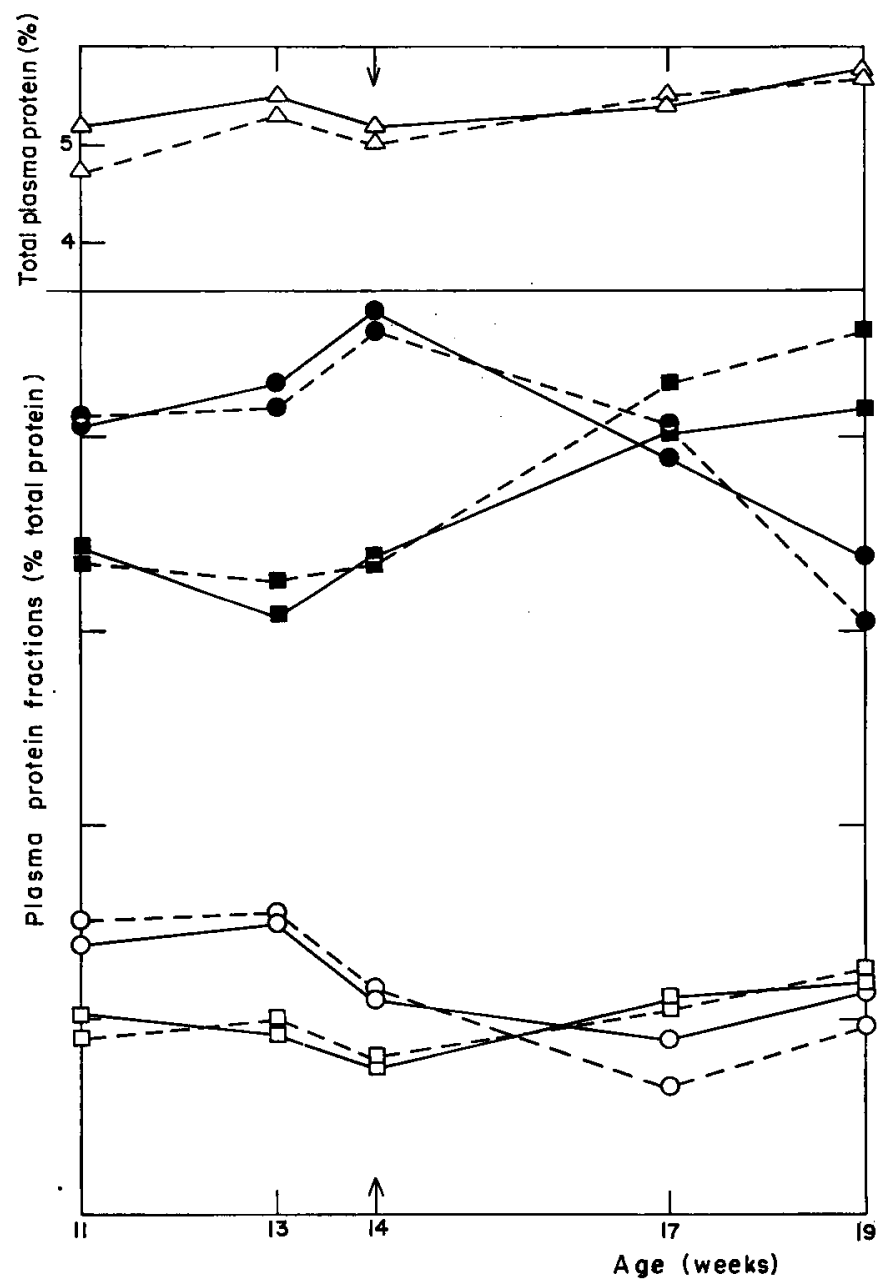

FIG. 2. - Total plasma protein and percentage of the different plasma protein fractions in geese fed diets containing 16 p. 100 or 28 p. 100 protein from the age of 4 weeks to start of forced feeding with cooked maize. (Arrows indicate start of forced feeding)

$$
\begin{aligned}
& 28 \text { p. Ioo protein }- \text { i } 6 \text { p. I00 protein - - - } \\
& \triangle P \text {. Ioo protein in plasma } \\
& \text { - P. roo albumin in plasma protein } \\
& \square \text { P. I oo a-globulin in plasma protein } \\
& \text { P. } 100 b \text {-globulin in plasma protein } \\
& \text { - P. } 100 \mathrm{~g} \text {-globulin in plasma protein } \\
& \text { (6 geese per treatment and period) }
\end{aligned}
$$

The only statistically significant difference $(P<0.05)$ between treatments was found in the total plasma protein at ir weeks of age.

G. 2. - Protéines plasmatiques totales et pourcentage des différentes fractions protéiques du plasma chez l'Oie recevant un régime contenant 16 p. 100 ou 28 p. 100 de protéines depuis l'áge de 4 semaines jusqu'au début du gavage avec du maïs cuit. (Les flèches indiquent le début du gavage). 
two weeks. Pre-albumin concentration was very low (about I p. Ioo). Its determination by the methods used was not accurate enough to permit the drawing of consistent deductions.

\section{DISCUSSION AND CONCLUSIONS}

Monachon (Ig68) reported on protein levels used by different workers for gosling diets. Most workers recommend a chicken starter mash (2I p. Ioo protein) during the first month. Subsequently mash formulation varies according to the quality and amount of green fodder administered to the birds.

In Istael, limited amounts of green fodder are given to the birds as most of the necessary nutrients are provided by the mash. In the present study, following the starter mash, a diet containing I6 p. Ioo protein, supplied essentially by soyabean meal and fish meal and supplemented with methionine resulted in optimal growth which was not improved by increasing the protein level.

The lack of effect of the richer protein diets during the preparatory period on fatty liver weight was in accordance with the results of BIELINSKI et al. (I968) who worked with 6-7 month old Italian geese.

Slightly increased weights of fatty livers obtained by FLEURET (I954) by proteinrich diets during the pre-fattening period might be of value in grazing geese receiving large amounts of green fodder with amino acid imbalanced mash.

Higher protein levels in the diet showed some effect on body organs at the end of the pre-fattening period. Livers and oesophagi were heavier in the $21 \mathrm{p}$. 100 protein diet fed to goslings. However this effect was not repeated in the second experiment with $28 \mathrm{p}$. Ioo protein diet and obviously had no effect on body organ weights following the fattening period. The $28 \mathrm{p}$. Ioo protein diet increased the pancreas and kidney weights, but again this trend did not persist on body, liver and organ weights following fattening.

Forced feeding caused a decrease in thyroid weights when related to body weight, while the adrenals remained unchanged. If we take into account that the increase in weight of the obese goose is mostly due to fat increment, then the thyroids remain unchanged and adrenal weights are increased when related to lean body weight.

It may be suggested that the relative increase in the adrenal weights expresses the state of stress promoted by forced feeding. In what measure the corticosteroid hormones are involved in the fatty liver syndrome of the forced-fed goose remains to be further elucidated.

Liver and muscle lipids and total protein content were not influenced by high protein diets during the preparatory period. The lack of effect was also observed in the plasma composition. Homeostatic mechanisms overcame the protein dietary excess which was only reflected by a very slight increase in the total plasma protein level and by lower free fatty acids values in plasma. LEwIS (rg64) found that the high free fatty acid-levels found in the plasma of kwashiorkor-affected children were lowered by protein treatment. In the present work additional protein in feed 
decreased free fatty acid levels in plasma of geese that did not suffer from protein deficiency. The effect was maintained even when the different diets were replaced by cooked maize.

The differences in plasma lipid concentration between the experiments conducted in winter and in summer are striking. These differences were obtained in birds of the same breed raised in the same premises and the only substantial differences were the seasonal conditions. In summer higher concentration of lipid P in plasma and liver, during the whole experimental period, was concomitant with lower concentration of plasma triglycerides during the fattening period. So far the effect of heat on triglycerides and phospholipid concentrations in plasma and liver has not been examined. These differences may also be the result of different behavior patterns during summer and winter.

The relationship between dietary protein level and plasma protein components in the chicken was described by NIR and ASCARELLI (Ig66-I967). They showed that a significant reduction in plasma protein was obtained only upon feeding 5 or Io p. 100 protein-containing diets.

In the present work a 28 p. Ioo protein diet increased, to a very slight extent, the plasma total protein level when compared to a $I 6 \mathrm{p}$. Ioo protein diet. Since maize is low in protein and deficient in essential amino acids, we expected to obtain a reduced plasma total protein level. This did not occur, on the contrary, the total plasma protein level was even slightly increased. The protein fraction response to simple protein deficiency was also different from that found in chicks (NIR et al., rg66-1967).

The albumin fraction decreased gradually during the first 3 weeks of forced feeding and very markedly during the last 2 weeks. This reduction could be attributed, at least partially, to the protein-deficient maize ; but the effect of forcedfeeding maize on $b$-globulins was opposite to that obtained in chickens fed poor protein diets. The $b$-globulins increased continuously throughout fattening and the increase in total proteins could be attributed, essentially, to this increase in $b$-globulins.

The reduced plasma albumin could be the result of the decreased capacity of the liver to synthesize albumin together with the development of steatosis, or/and the result of feeding protein and amino acid-deficient maize.

The increase in $b$-globulins may be a reflection of the increased $b$-lipoproteins involved in fat transportation in the plasma of obese geese. $b$-lipoproteins migrate with the $b$-globulin zone in most types of electrophoresis separation. The same trend was actually found with the $a$-globulins which migrate with the $a$-lipoprotein zone.

According to FREDERICKSON et al. (I967) the main transporters of glycerides synthesized in the liver are $b$-lipoproteins. To what extent the increase in $a$ - and $b$-globulins was due to $a$ - and $b$-lipoproteins and what is the site of this increased synthesis, i.e. liver or extra-hepatic origin, remain to be determined.

Whatever were the causes affecting the changes in the plasma protein pattern of the obese geese, a high protein diet before fattening had no effect on this phenomenon as on most of the other phencmenons measured in this experiment during and at the end of the fattening period. 


\section{ACKNOWLEDGEMENT}

This work was generously supported by the Samuel and Esther Lipman Foundation, Augusta, Maine, U. S. A.

\section{RÉSUMÉ}

\section{EFFET DE DEUX NIVEAUX PROTÉIQUES DANS LA NOURRITURE DES OISONS PENDANT LA PÉRIODE PRÉPARATOIRE SUR LA PRODUCTION DU FOIE GRAS ET LES COMPOSANTS DU PLASMA SANGUIN}

Deux expériences ont été menées pour étudier l'effet de régimes riches en protéines pendant la période préparatoire à l'engraissement sur la production du foie gras chez l'Oie. Aucun effet sur le poids et la composition lipidique des foies, sur les organes et sur les lipides et les protéines plasmatiques des Oies après l'engraissement n'a été mis en évidence.

\section{REFERENCES}

Abell L. L., Levy B. B., Kendall F. E., 1952. A simplified method for the estimation of total cholesterol on serum and demonstration of its specifity. J. Biol. Chem., 195, 337-366.

Bielinski K., Bielinska Krystyna, Kaszynski J., rg68. An attempt to establish the effect of feeding geese with high protein rations during preparatory period for fatty liver production. Postepy Drobiarstwa, 10, I53-I58.

Fleuret P.-H., r954. La production du foie gras de volaille destiné à la consommation. J. Sci. Centre Nat. Coord. Etud. Recherche Nutr. Aliment. V. Phys. pathol. chimie et cytol. des foies gras, Paris, 97-I3I.

Frederickson D. S., Levy R. I., Lees R. S., I967. Fat transport in lipoproteins - an integrated approach to mechanisms and disorders. Medical Progress, reprinted from the New England. J. Med., 276, 32-44, 94-I03, I48-156, $215-226,273-28 \mathrm{r}$.

ItAYA K., Ur M. J., 1965. Colorimetric Determination of Free Fatty Acids in Biological Fluids. J. Lip. Res., 6, 16-20.

Lewis B., Hansen J. D. L., Wittman W., Krut L. H., Stewart F., 1964. Plasma free fatty acids in Kwashiorkor and the pathogenesis of the fatty liver. Am. J. Clin. Nutr., 15, 16r-168.

Monachon G., 1968. Table ronde du B. N. A. Paris, 5 mars.

Nelson N. A., 1944. A photometric adaptation of the Somogoyi method for the determination of glucose. J. Biol. Chem., 163, 375-380.

Nir I., Ascarelli I., I966. Effect of dietary protein and thyroxine on vitamin A depletion from liver in chicks. $\mathrm{Br} . J$. Nutr., 20, 4r-52.

Nir I., Ascarelli I., r967. Effect of dietary protein level and thyroxine on vitamin A absorption and plasma proteins in chicks. Br. J. Nutr., 21, 167-180.

Searcy R. L., Bergquist L. M., I96o. A new color reaction for the quantitation of serum cholesterol. Clin. Chem. Acta, 5, I92-rg9.

VAN HANDel E., I96r. Suggested modifications of the microdeterminations of triglycerides. Clin. Chem., 7, 249-251.

Youngbourg G. E., Youngbourg M. V., i93o. J. Lab. Clin. Med., 16, 158. As described by P. B. Hawk, B. L. Oser, W. H. Summerson. In : Pratical Physiological Chemistry I3th ed., McGraw-Hill N. Y., I954, p. 589 . 